\title{
Assurance of Learning (AOL) Case Study in a Capstone Finance Course at Indiana University South Bend
}

\author{
Raj K. Kohli \\ Indiana University South Bend. \\ United States
}

\begin{abstract}
Assurance of Learning (AOL) has become an increasingly important dimension in Association to Advance Collegiate Schools of Business (AACSB) evaluation standards. In this case study, the author has developed and used a distinct AOL model to measure the impact on students learning in a capstone finance course at a state university in Indiana. Direct assessment of students learning is tested in closely controlled classroom environment through exam. The findings of the AOL model application indicate average scores of $\mathbf{8 1 . 6 1}$ percent for the semester, 85.67 percent for uncontrolled non-AOL model application environment, and 58.60 percent for controlled AOL model application condition respectively. Eighteen of twenty students in the study performed poorly in the AOL model application category than non-AOL model category. A poor performance in AOL model category indicates that the AOL model developed for this study successfully measures Assessment Process.
\end{abstract}

Keywords: Direct Assessment of Student Learning; Assurance of Learning; AACSB AOL Standards

\section{BACKGROUND}

Assessment is an important factor of improved education on the part of faculty, students and programs. It provides feedback from which those involved can learn and make necessary changes to enhance the learning environment Educational assessment is the amount of knowledge, skills, or benefits in terms that can be accounted for or measured (Ben-Jacob, 2017). Business schools are tending toward a managerial training and skills development model of education. In doing so, the mission of preparing students for jobs and careers in the business world with a demonstrable, ready-made skill set tends to take precedence over the more broad aims of liberal education (Kilpatrick and Kilpatrick, 2008).

Assurance of Learning (AOL) has become one of the important dimensions in AACSB evaluation standards of business schools. In this article, the author has developed and used a distinct AOL model, to measure the impact on students learning in a capstone finance course at a state university in Indiana.

Assurance of Learning continues to play an important role in continuous improvement and is positioned within the broader context of curriculum management. (2013 Revised AOL Standards - AACSB). With the adoption of the 2003 standards, there was a shift from schools primarily using indirect measures such as student and employer surveys to direct measures. The need for direct measures continues to be present in the 2013 standards. AACSB Assurance of Learning Standards: 20 November 2007 - Revised 3 May 2013

Accountability and Continuous improvement are two basic AOL standards on which AACSB accreditation mainly depends. While learning measures may be assessed through external constituents in accountability, continuous improvement may be measured internally by evaluating student's success. 
Palomba and Banta (1999) state that the outcomes assessment process should include:

a. What will our students learn in our program? What are our expectations?

b. How will they learn it?

c. How will we know they have learned it or not?

d. What will we do if they have not learned it?

This article, examines and tests the above-mentioned four outcomes assessment processes in a course at Indiana University South Bend. A systematic model developed to test the above four assessment processes is explained in the section.

\section{FOUR ASSESSMENT PROCESSES \\ Assessment Process \#1. What will our students learn in our program? What are our expectations?}

Assessment process \#1 is tested in a non-structured capstone finance course entitled, "Applications in Financial Management" of the finance program at a State University in Indiana. Students learn to apply knowledge acquired from the previous finance courses by analyzing and solving comprehensive finance cases with extensive spreadsheet applications. In addition, students learn the importance of collegiality by effectively working with their colleagues in groups.

The finance program expects them to understand importance of collaborative learning, collegiality, understanding and applications of financial management concepts. The purpose of this capstone finance course is to let students apply financial concepts and techniques to real life situations, develop skills in the analysis of financial problems and apply the knowledge gathered from previous finance courses. A general format for the course is to place students in a consulting like business situation in which he/she must make a decision regarding a complex financial problem.

\section{Assessment Process \# 2. How will they learn it?}

This capstone course of the finance program is a self-learning, non-structured class designed for finance majors only. Students spend significant time completing this course, perhaps more than the time spent on any other two senior level business courses at the business school. To compensate students for the extra time and efforts needed to complete this course, the class does not take any regular exam. However, students are required to solve one in-class individual case as final exam in order to demonstrate the individual learning outcome. The model in question is specifically applied for testing the final exam in a closely controlled classroom environment. Assessment process \#3 explains the details of the AOL model.

This course is a combination of case analysis, presentation, spreadsheet application, and discussions with minimal essential review lectures. Case solutions require the application of various theories and concepts covered in prerequisite finance classes. Two to three cases on each topic of capital budgeting, cost of capital, discounted cash flows, leasing, risk and return, valuation, mergers, and long term financing are covered during the semester.

The class begins with the professor solving a comprehensive case on any one of the finance topics mentioned in the preceding paragraph. Altogether, the professor spends about three to four class meetings of 75 minutes each in solving one comprehensive course from scratch. He shows them the meaning of thoroughness, completeness, accuracy of the solution, and of the spreadsheet model. For instance, any data or information is allowed to enter only once in the spreadsheet, e.g., price of a project $\$ 500,000$ should be entered only once in the spreadsheet 
model even though it is needed to solve various questions answered in the multiple interlinked worksheets. Once the professor finishes his/her case presentation, student groups present cases for remainder of the semester.

Professor assigns students to various groups depending on their academic capacity, demographic and background diversity. Students are assigned to different groups for each case presentation round. At times, there may be a minor deviation in this policy depending on the class size and available permutations. The process of changing group members in each round possibly reduces students' comfort zone but increases diversity, collegiality and collaboration among peers. Further, in order to reduce conflict and impact on group members' relationship, professor carefully considers all information before entertaining group members' complaints.

Altogether, five groups of about four students present approximately 20 finance cases during the semester. Each group is held responsible for analyzing, organizing, solving and presenting the case to the class on a specified date. At the end of each case presentation, the professor provides feedback, comments, corrections and suggestions to the group. Students are encouraged to challenge the professor's feedback with substantiated justifications without fear of backlash. The grade for the case presentation depends on two dimensions; (a) thoroughness, completeness, accuracy, and applications of financial management concepts; and (b) completeness, accuracy, unrepeated data entry, and properly interlinking worksheets in the spreadsheet model.

In order to maintain comparative grading standards, professor assigns letter grades to the group at the end of case presentation round. All four-group members receive the same grade for an assigned case regardless of the quality and quantity of an individual's contribution to the case. However, at this time, students are asked to grade their peers. In general, students share candidly on their peers' contribution levels and the professor may further penalize them depending on peers' feedback pattern. Altogether, peers evaluations constitute seven and half percent of the semester grade.

\section{Assessment Process \#3. How will we know they have learned it or not?}

As stated earlier, each group analyzes, solves and presents about five finance cases during the semester. Students solve cases by applying knowledge of finance topics learned from previous courses. In addition, they are required to enter the case solution in a thoroughly prepared spreadsheet. The grades depend on two dimensions; (a) thoroughness, completeness, accuracy, and applications of financial concepts and (b) completeness, accuracy, unrepeated entry of data, and interlinking of multiple worksheets.

In addition to grading students' work through case presentations during the semester, a customized AOL assessment process model is specifically developed and tested for this class. Presumably, a comprehensive and cheating proof final exam was proctored in spring semester 2017*.

\section{Assessment Process \#4. What will we do if they have not learned it?}

Development, application of a newly suggested and tested AOL model for a capstone finance course at a state university in Indiana indicates successful results of the Assessment Process \#3. These findings indicate that the finance program may comfortably state that students learned and applied the required concepts in this specific course. The faculty member would have to redesign the proposed AOL model if the students did not successfully learn it. Still, the model can be further modified and probably applied in other finance courses. 
CUSTOMIZED AOL EVALUATION METHOD FOR ASSESSMENT PROCESS \#3 AND RESULTS

The exam proctoring method is explained in this section. To ensure a comprehensive cheating proof process of students' understanding of concepts and application, a four steps evaluation process is used.

\section{Step I. A completely customized exam administered in a computer lab}

Students were informed in advance that the final exam would be a customized finance case either on capital budgeting or cost of capital topics. Students were actually tested on a customized case (Table 1) on capital budgeting in April 2017. In order to test the validity of tested concepts, the exam was shown and Okayed by two other finance professors for accuracy, clarity and completion time.

\section{Table 1 - Exam Type A}

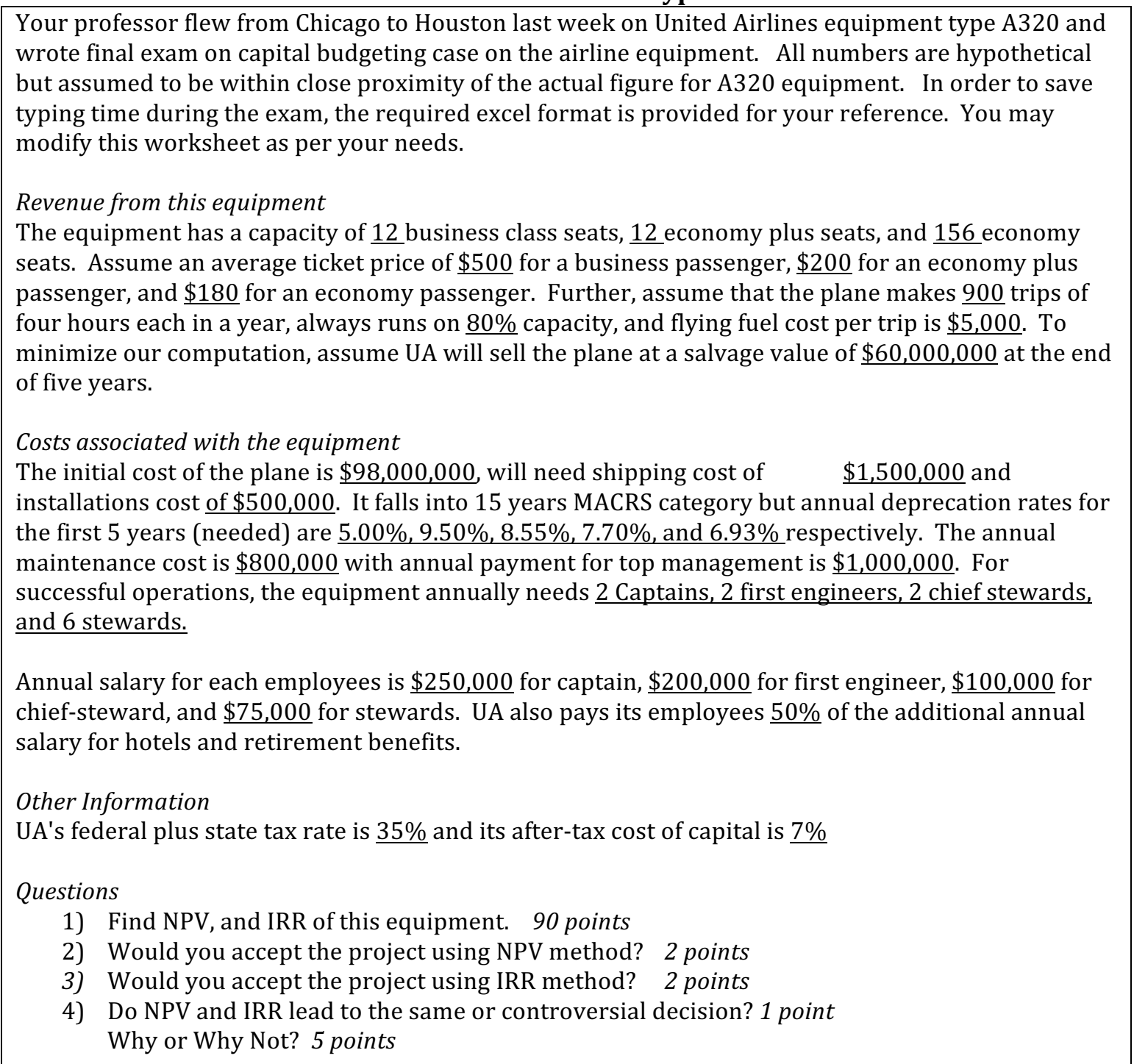

\section{Step II. Spreadsheet Model}

Overall, 20 students enrolled in the class. Each student was given an Excel template with a locked cell (Student \#1 to \#20). A random student \# for each student was used because the excel file with student names cannot be posted on website due to Family Educational Rights and Privacy Act (FERPA) regulations. The process of locking student \#s in the provided Excel 
template guarantees that students cannot share their Excel work with peers. Hence, the results of the exam directly measure if students learned and applied the topics correctly.

Students were given the following formatted Excel template (Table 2) to save typing time and to increase time available for analyzing applying the finance concepts into Excel.

Table 2 - Panel A

Final Exam F444- Applications in Financial Management; Spring 2017

\begin{tabular}{|c|c|c|c|c|c|}
\hline & A & $\mathrm{B}$ & C & $\mathrm{D}$ & $E$ \\
\hline 1 & \multicolumn{5}{|c|}{ F444 Final Exam (Case on Capital Budgeting): 4/27/2017 (United Airlines Equipment Type A320) } \\
\hline 2 & & & & & \\
\hline 3 & Initial Cost of the Plane & & & & \\
\hline 4 & Shipping Cost & & & & \\
\hline 5 & Installations Cost & & & & \\
\hline 6 & MACRS Rates (See depreciation area) & & & & \\
\hline 7 & Number of Employees & Captain & $\begin{array}{l}\text { First } \\
\text { Engineer }\end{array}$ & $\begin{array}{l}\text { Stewar- } \\
\text { dess }\end{array}$ & $\begin{array}{l}\text { Stewar- } \\
\text { dess }\end{array}$ \\
\hline 8 & Employees Salary & & & & \\
\hline 9 & Employees' additional benefits & & & & \\
\hline 10 & Seating Capacity & Business & $\begin{array}{l}\text { Econom- } \\
\text { my Plus }\end{array}$ & Economy & \\
\hline 11 & Number of Seats & & & & \\
\hline 12 & Price per seat & & & & \\
\hline 13 & Capacity of occupancy & & & & \\
\hline 14 & Salvage Value & & & & \\
\hline 15 & The annual maintenance cost is & & & & \\
\hline 16 & Annual payment for top management & & & & \\
\hline 17 & Number of trips per year & & & & \\
\hline 18 & Flying fuel cost per trip & & & & \\
\hline 19 & UA's federal plus state tax rate & & & & \\
\hline 20 & After-tax cost of capital & & & & \\
\hline 21 & & & & & * \\
\hline 22 & Annual Ticket Sales Revenue per Trip & & & & \\
\hline 23 & Type of Seats & $\begin{array}{l}\text { Number of } \\
\text { Seats }\end{array}$ & \begin{tabular}{|l} 
Ticket \\
Sales \\
\end{tabular} & Revenue & \\
\hline 24 & Business Class & & & & \\
\hline 25 & Economy Plus & & & & \\
\hline 26 & Economy & & & & \\
\hline 27 & Total possible Revenue per Trip & & & & \\
\hline 28 & & & & & $*$ \\
\hline 29 & Total annual Ticket Sales revenue & & & & \\
\hline 30 & & & & & \\
\hline 31 & Employees annual compensation & & & & \\
\hline 32 & Employee Type & Number & Salary & Total Salary & \\
\hline 33 & Captain & & & & \\
\hline 34 & First Engineer & & & & \\
\hline 35 & Chief Stewardess & & & & \\
\hline 36 & Stewardess & & & & \\
\hline 37 & & & & & $*$ \\
\hline 38 & Total Employees annual compensation & & & & \\
\hline
\end{tabular}


Table 2 - Panel B

Final Exam F444- Applications in Financial Management) Spring 2017

\begin{tabular}{|c|c|c|c|c|c|c|c|c|}
\hline & $\mathrm{A}$ & $B$ & $\mathrm{C}$ & $\mathrm{D}$ & $\mathrm{E}$ & $\mathrm{F}$ & G & $\mathrm{H}$ \\
\hline 44 & Purchase price of the plane & & Year & Rate & Amount & Book Value & & \\
\hline 45 & Shipping cost & & Year 1 & $5.000 \%$ & & & & \\
\hline 46 & Installation cost & & Year 2 & $9.500 \%$ & & & & \\
\hline 47 & Depreciable Base & & Year 3 & $8.550 \%$ & & & & \\
\hline 49 & & & Year 5 & $6.930 \%$ & & & & \\
\hline 50 & & & & & & & & \\
\hline 51 & Computation for Cash Flows & Year 0 & Year 1 & Year 2 & Year 3 & Year 4 & Year 5 & \\
\hline 52 & Annual Ticket Sales Revenue & & & & & & & \\
\hline 56 & Annual payment to top management & & & & & & & \\
\hline 57 & Depreciation & & & & & & & \\
\hline 58 & EBIT & & & & & & & \\
\hline 59 & Taxes & & & & & & & \\
\hline 60 & After tax income & & & & & & & \\
\hline 61 & Add back depreciation & & & & & & & \\
\hline 62 & Net operating cash flows & & & & & & & \\
\hline 63 & & & & & & & & $* *$ \\
\hline 69 & & & & & & & & \\
\hline 70 & NPV and IRR Calculations & & & & & & & \\
\hline 71 & NPV & & & & & & & \\
\hline 72 & IRR & & & & & & & \\
\hline 73 & & & & & & & & \\
\hline 74 & *These rows are kept purposefully empty for stu & think & Ill if nee & & & & & \\
\hline 75 & **These rows are kept blank for good visibility & & & & & & & \\
\hline
\end{tabular}

\section{Step III: LanSchool Classroom Management Software}

LanSchool software was used in the computer lab to monitor students' activities while taking the exam with computers. Cell phones (and hence cameras) were not allowed during the exam. This process of no cell phones or cameras guarantees that students cannot share the Excel work with peers via texting or other external means.

A completely customized exam, non-duplicable formatted spreadsheet for each student, not allowing cell phones (hence cameras) during exam along with monitoring the computer with LanSchool software almost guarantees cheating proof examination. The results of the application of this model directly measure if students learned and applied topics properly.

Altogether, 20 students took the exam using this model. The findings of the AOL application model in classroom with negligible chance of cheating are reported below. 


\section{RESULTS}

Table 3 shows the results of the above-mentioned cheating proof AOL model specifically developed and applied for this course. It is expected that the grades without AOL model application must be greater than grades with AOL model application.

Students' Performance for all Works Excluding AOL Model Application - Column B of the table shows students' grades for all works completed during the semester excluding final exam. A further look at column B shows an average score of 85.67 percent with standard deviation of 3.65 percent and median score of 85.85 percent. These results indicate that students' performance for all groups is close to each other with insignificant deviation. This may imply that students could be collaborating and helping each other in this unmonitored part of the performance evaluation. Students' scores range from low of 74.18 percent to high of 91.04 percent. Eight five percent of the semester grade belongs to this category. Thus, it is reasonable to interpret from these findings that the class would pass this course with a score of 85.67 percent letter grade of $\mathrm{B}$.

Students' Performance for all Works Performed under AOL Model Application - Column C of the table indicates students' grades for AOL model part of the final exam that constitutes fifteen percent of the semester grade***. This column indicates an average score of 58.60 percent (substantially below average score of 85.85 percent in Column B) with a standard deviation of 16.62 percent and median score of 59 percent. Students' individual scores range from low of 23 percent to high of 95 percent. Eighteen of twenty students' academic performance was weak in this monitored classroom environment than uncontrolled out of class environment. These results indicate that students' performance for the group as a whole is not close with each other and has a wider and normally acceptable standard deviation. These results may also indicate that students were not able to collaborate and help each other in the closely monitored performance evaluation environment. Thus, it may be interpreted from the findings that the application of AOL model successfully measured students learning outcomes.

Students' Performance for the Semester Including AOL Model Application - Column D of table III shows students' overall grades for the semester. This column of table indicates an average score of 81.61 percent (substantially higher than the average score of 58.60 percent in column $\mathrm{C}$ above) and a standard deviation of 4.35. Students' individual scores range from low of 71 percent to high of 88.77 percent, and median grade of 82.17. These results indicate that students' average performance dropped from 85.67 percent in non-AOL model category to 81.61 percent for the semester. This drop may probably be due to substantially poor performance in the AOL model category.

Test of Assessment Process \#3 or Difference between Semester Grade and AOL Model Grade A closer look at column $\mathrm{F}$ shows that eighteen of twenty students' performance was better in all but AOL model grades than the AOL model grades. On average, students' performance decreased in the AOL model grades from non-AOL model grades by an average of 27.07 percent. A further look at column F shows that only two of 20 students performed better in the AOL model category than non-AOL model category. Thus, a poor performance in AOL model category than the remaining categories indicate that the AOL model developed for this course successfully measured Assessment Process \#3. 
Table 3

Grade Distribution for the Semester, non-AOL Model Application and AOL Model Application

\begin{tabular}{|c|c|c|c|c|c|c|c|}
\hline & A & B & C & $\mathrm{D}$ & $E$ & $\mathrm{~F}$ & $\bar{G}$ \\
\hline 1 & \multicolumn{7}{|c|}{ F444 (Applications in Financial Management) } \\
\hline 2 & Spring 2017 & \multicolumn{6}{|c|}{ Grades } \\
\hline 3 & & 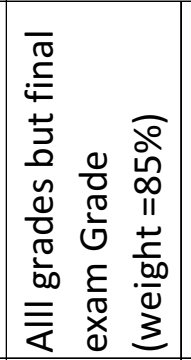 & 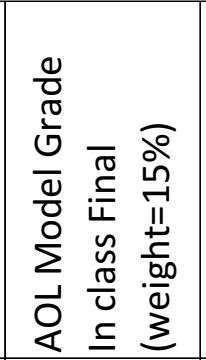 & 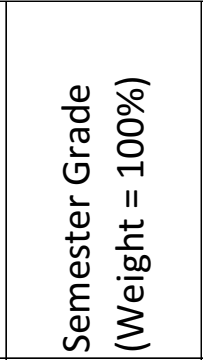 & & 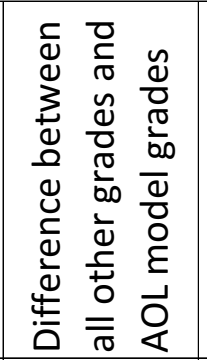 & 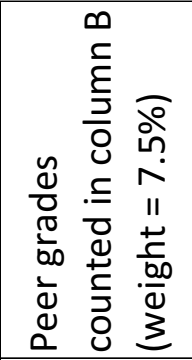 \\
\hline 4 & & Percent & Percent & Percent & & Percent & Percent \\
\hline 5 & Student \#1 & 74.18 & 53 & 71.00 & & 21.18 & 20.00 \\
\hline 6 & Student \#2 & 86.00 & 55 & 81.35 & & 31.00 & 71.50 \\
\hline 7 & Student \#3 & 83.57 & 64 & 80.63 & & 19.57 & 63.60 \\
\hline 8 & Student \#4 & 87.66 & 70 & 85.01 & & 17.66 & 64.50 \\
\hline 9 & Student \#5 & 85.70 & 50 & 80.35 & & 35.70 & 71.25 \\
\hline 10 & Student \#6 & 88.52 & 64 & 84.85 & & 24.52 & 71.25 \\
\hline 11 & Student \#7 & 87.14 & 60 & 83.07 & & 27.14 & 63.60 \\
\hline 12 & Student \#8 & 82.62 & 23 & 73.68 & & 59.62 & 50.25 \\
\hline 13 & Student \#9 & 87.46 & 58 & 83.04 & & 29.46 & 60.00 \\
\hline 14 & Student \#10 & 87.46 & 60 & 83.34 & & 27.46 & 64.00 \\
\hline 15 & Student \#11 & 91.04 & 67 & 87.43 & & 24.04 & 64.50 \\
\hline 16 & Student \#12 & 85.70 & 50 & 80.34 & & 35.70 & 51.23 \\
\hline 17 & Student \#13 & 85.35 & 71 & 83.20 & & 14.35 & 68.63 \\
\hline 18 & Student \#14 & 83.80 & 60 & 80.23 & & 23.80 & 58.50 \\
\hline 19 & Student \#15 & 81.66 & 45 & 76.16 & & 36.66 & 60.00 \\
\hline 20 & Student \#16 & 88.45 & 52 & 82.98 & & 36.45 & 64.50 \\
\hline 21 & Student \#17 & 88.55 & 90 & 88.77 & & -1.45 & 70.50 \\
\hline 22 & Student \#18 & 83.54 & 55 & 79.26 & & 28.54 & 27.90 \\
\hline 23 & Student \#19 & 89.89 & 30 & 80.90 & & 59.89 & 64.50 \\
\hline 24 & Student \#20 & 85.03 & 95 & 86.53 & & -9.97 & 63.74 \\
\hline 25 & & & & & & & \\
\hline 26 & Total Students & 20.00 & 20.00 & 20.00 & & 20.00 & 20.00 \\
\hline 27 & Mean & 85.67 & 58.60 & 81.61 & & 27.07 & 59.70 \\
\hline 28 & S.D. & 3.65 & 16.62 & 4.35 & & 16.29 & 13.59 \\
\hline 29 & Maximum & 91.04 & 95.00 & 88.77 & & 59.89 & 71.50 \\
\hline 30 & Minimum & 74.18 & 23.00 & 71.00 & & -9.97 & 20.00 \\
\hline 31 & Median & 85.85 & 59.00 & 82.17 & & 27.30 & 63.87 \\
\hline 32 & Mode & 87.46 & 60 & $\# N / A$ & & $\# N / A$ & 64.5 \\
\hline
\end{tabular}

\section{Closing the Loop of Learning Process}

AOL involves a cyle of continuous improvement of curricula, with schools regualrly assesing and improving their programs to ensure essential student competenceis (Rexisen and Garrison, 2013). In order to evaluate the validity and reliability of this newly developed AOL process for the course, students were asked to complete a survey after submitting their exams. They were 
awarded a 2 percent bonus in the final exam for completing the survey. A very high response rate of 90 percent (18/20 responses) was achieved with an initial call for survey and two subsequent reminders.

Panel A of Table IV shows the questionnaire instrument sent to students using 5 5-point Likert Scales measuring exam fairness with 1 (strongly disagree response) and 5 (strongly agree response). Results of the survey (reported in Panel B of table 4) show the mean of 4.44 and 4.00 for fairness of the exam and acceptable difficulty level of exam respectively. Respondents indicated that time allotted for completing the exam was enough (mean 4.72). In addition, respondents replied with means of 4.33 that the topics in exam were covered during the semester. More importantly, the mean score of 4.33 implies less than 2 percent chances of cheating in the exam. Thus, respondents' answers also show that the developed AOL model was successful in testing Assessment Process \#3.

Table 4-Panel A

Survey Quesionnaire (Final Exam F444- Applications in Financial Management) Spring 2017

\begin{tabular}{|c|c|c|c|c|c|c|c|}
\hline & A & $\mathrm{B}$ & $\mathrm{C}$ & $\mathrm{D}$ & $\mathrm{E}$ & $\mathrm{F}$ & $G$ \\
\hline 1 & Excel File - Survey for the final exam (F444) & & & & & & \\
\hline 2 & Capital Budgeting Case 4/27/2107 & & & & & & \\
\hline 3 & & \multicolumn{6}{|c|}{ Please put an $\mathrm{x}$ in row only once as applicable } \\
\hline 4 & & 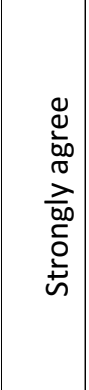 & 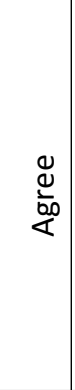 & 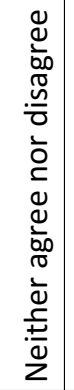 & 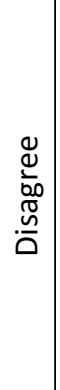 & 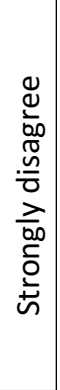 & \\
\hline 5 & Exam was fair & & & & & & * \\
\hline 6 & Difficulty level of the exam was ok & & & & & & * \\
\hline 7 & Time allotted was enough to complete the exam & & & & & & * \\
\hline 8 & Topics in exam were covered during the semester & & & & & & * \\
\hline 9 & & ஃ̊ & 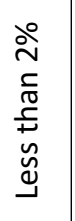 & 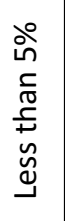 & 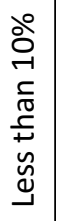 & 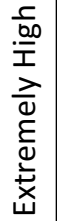 & \\
\hline 10 & Probable chances of cheating during exam were & & & & & & * \\
\hline 11 & & & & & & & \\
\hline 12 & *Please put $x$ only in one cell of this row & & & & & & \\
\hline 13 & Make sure you enter only 5 " $X$ " in five differen & laded & OWs & above & & & \\
\hline 14 & Survey is invalid if more than 5 " $X$ " or less that & $\mathrm{X}$ "are & ente & & & & \\
\hline
\end{tabular}

Table 4-Panel B

Survey Results (Final Exam F444- Applications in Financial Management) Spring 2017

\begin{tabular}{|c|c|c|c|c|c|}
\hline & A & $\mathrm{B}$ & $\mathrm{C}$ & $\mathrm{D}$ & $\mathrm{E}$ \\
\hline 19 & & Mean & Median & S.D. & Count \\
\hline 20 & Exam was fair & 4.44 & 4.00 & 0.51 & 18 \\
\hline 21 & Difficulty level of the exam was ok & 4.00 & 4.00 & 0.69 & 18 \\
\hline 22 & Time allotted was enough to complete the exam & 4.72 & 5.00 & 0.46 & 18 \\
\hline 23 & Topics in exam were covered during the semester & 4.33 & 4.00 & 0.69 & 18 \\
\hline 24 & & & & & \\
\hline 25 & Probable chances of cheating during exam were & 4.33 & 5.00 & 1.03 & 18 \\
\hline
\end{tabular}




\section{CONCLUSION}

An in-class exam to ascertain Assurance of Learning was developed, implemented and tested in a capstone course of the finance program. After the author developed the case, the exam was shown and approved by two finance professors for accuracy, clarity, and time constraint. Twenty finance students in a capstone course took the exam using this AOL model.

Students' performance for their works during the semester, performance in all works excluding AOL model application, and performance on AOL model application is analyzed in this study. The results show average scores of 81.61 percent, 85.67 percent and 58.60 percent with standard deviations of 4.35 percent, 3.65 percent and 16.62 percent respectively in three categories. These results indicate that students' average performance dropped from 85.67 percent for non-AOL model category to 81.61 percent for the semester. This drop may be attributed to substantial poor performance in the AOL model category.

The results also show that 18 of 20 students' performance was better in non-AOL model grades than in AOL model grades. On average, students' performance decreased in the AOL model grades from non-AOL model by an average of 27.07 percent. Only two of 20 students performed better in the AOL model category than in non-AOL model category. A poor performance in AOL model category indicates that the AOL model developed for this course successfully measures Assessment Process \#3. Overall, the results of this in class case solving exams with use of unrestricted available resources is effective and positively affects student learning.

Neighboring students were given exam type A or type B to minimize probability of copying from adjacent peers. Since the exam was custom made, so the chances of getting information from Internet are almost zero. Exams A and B were essentially same except different input data numbers.

\section{References}

Ben-Jacob, Marion G., Assessment: Classic and Innovative Approach, Open Journal of Social Sciences, 2017, 5, pp. 4651

Kilpatrick, John, and Kilpatrick Paul, Philosophical Concerns About Interpreting AACSB Assurance of Learning Standards, Journal of Management Inquiry, Vol 17, No. 3, September 2008, pp. 200-212.

Marchewka, Jack T., Applying the Capability Maturity Model to Assurance of Learning, Communication of the IIMA, 2013, Vol 13, Issue 1, pp. 1-16

Palomba, C.A., and T. W. Banta, Assessment Essentials. San Francisco, CA., Josey-Bass, 1999

Rexisen, Richard J., and Garrison, Michael A., Closing-the-Loop in Assurance of Learning Programs: Current practices and Future Challenges, UST Research Online, 2013. 